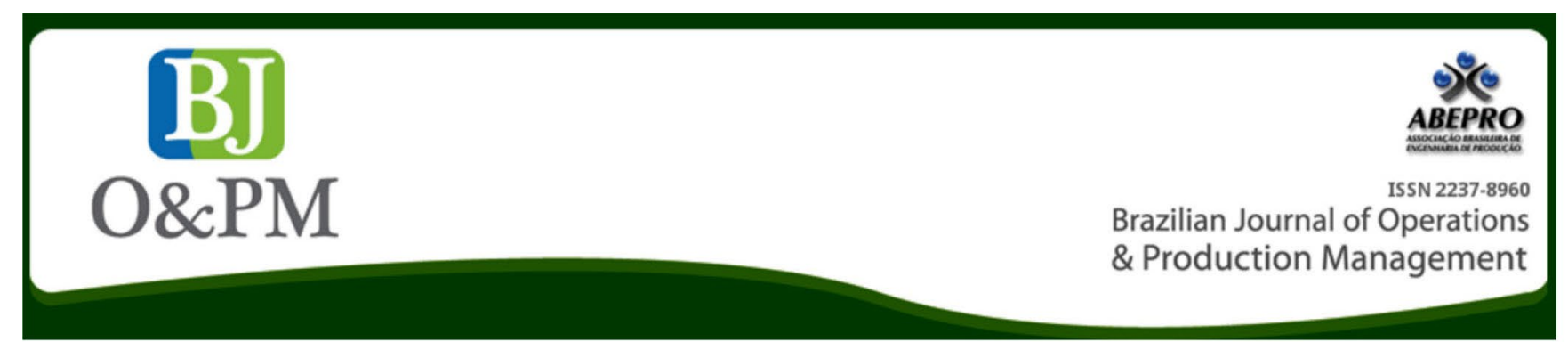

\title{
KNOWLEDGE MANAGEMENT ALIGNMENT TO THE COMMUNITY OF PRACTICE IN A COMPANY OF CUTTING AND BENDING STEEL
}

Taciana de Barros Jerônimo taciana.barros@gmail.com PLANASP Research Group, Center for Applied Social Sciences, Federal University of Pernambuco - UFPE, Recife, Pernambuco, Brazil

Fagner José Coutinho de Melo fagnercoutinhomelo@gmail.com PLANASP Research Group, Center for Applied Social Sciences, Federal University of Pernambuco - UFPE, Recife, Pernambuco, Brazil

\section{Joás Tomaz de Aquino}

joastomaz@outlook.com PLANASP Research Group, Center for Applied Social Sciences, Federal University of Pernambuco - UFPE,

Recife, Pernambuco, Brazil

\section{André Philippi Gonzaga de} Albuquerque

andre_philippi@hotmail.com PLANASP Research Group, Center for Applied Social Sciences, Federal University of Pernambuco - UFPE, Recife, Pernambuco, Brazil

Denise Dumke de Medeiros medeirosdd@gmail.com PLANASP Research Group, Center for Applied Social Sciences, Federal University of Pernambuco - UFPE, Recife, Pernambuco, Brazil

\begin{abstract}
This article aims to analyze the characteristics of a community of practice focused on the quality of management decision making in a company in the metallurgical industry, which is a company of cutting and bending steel for construction. Quality management requires greater flexibility in the activities, information sharing, skills development of individuals, and engagement among employees. The scientific method adopted was the descriptive cross-analysis case study, whose data was collected through semi-structured interviews conducted with 180 individuals. It was observed that the creation of communities of practice does not occur at random, and its main features are defined identity of shared interest; the way to build the image belonging to a particular social group; and involvement in joint activities that allow them to learn from each other.
\end{abstract}

Keywords: Organizational Learning; Quality management; Knowledge management 


\section{INTRODUCTION}

Knowledge management (KM) is an emerging field of research that is valued in the modern times (Zeide et Liebowitz, 2012). It is capable of creating a competitive advantage that is hard to imitate, and is rooted in people working in the company, who are more flexible in responding to environmental uncertainties (Demarest, 1997). The KM management model adopted for companies with the objective of increasing and sharing as information for the development of skills and intellectual capital of individuals (Gonçalves et al., 2009).

Thus, it is important that each department of a company is permeated by employees who know how to use knowledge for the proper development of routines and for more assertive decision making. According to Fresneda et Goulart (2006), there are a multitude of problems already identified by the absence of the KM in a company. They are: existence of great mass of strategic information not treated and not disseminated to decision makers; individual and collective skills not exploited; insufficient intra-organizational collaboration; low utilization of group, collaborative and virtual work and difficulty in terms of promoting collective learning, constituting a barrier to creativity and innovation.

In the process of quality management, there is an increasing flexibility in the activities of the functional areas and departments of the company, in order to contribute to the mutual engagement of all employees for KM and organizational learning (Wenger, 2000). It should also be considered that the competitive power of a company is more related to its intellectual capabilities of service (technological know-how, product design, marketing presentation, customer understanding, personal creativity and innovation) than in its fixed assets (Santos et Amato Neto, 2008).

Nadler et Tushman (2000) argue that, for KM to influence operation and involve quality management processes, it is necessary to analyze three critical points of the organizational environment: i) requirements for the organization, such as new / improved products or services with a certain level of quality; ii) restrictions or limitations imposed on the organizational action, such as capital shortage, human resources, use of advanced technology, among others; iii) opportunities to be explored.

These demands, constraints, and opportunities are not considered new to organizations. The main difference is how companies can learn, develop their activities and thus continuously improve, being able to adapt to the external environment; at the same time, being able to plan their internal actions with long-term projection.

According to Nonaka et Takeuchi (1997), KM is able to create new knowledge, recreating the processes that exist in the company as an organizational and personal renewal. The latter form is born by the elaboration and amplification of knowledge at the level of the individuals that work together as a community. Nonaka et Takeuchi (1997) differentiate tacit and explicit knowledge. Tacit knowledge consists of subjective knowledge (skills, ideas, perception and the experience of a person). It is difficult to be institutionalized, formalized, transferred or explained to another person. On the other hand, explicit knowledge is the knowledge formalized in texts, graphs, tables, figures, drawings, and diagrams, since it is easy to transmit and to use. In this way, the organization must support individuals with creativity and provide contexts for the creation of knowledge.

Lopes et Valentim (2013) arrogate that, when considering the aspects that foster the creation of knowledge through the management of informational contents, one can surely lead the company to stand out in the highly competitive market.

This article aims to analyze the characterization of a community of practice focused on decision making in quality management in a metallurgical sector company, based on knowledge management. This company has, as its main activity, the cutting and folding of steel for civil construction.

The importance of studying the metallurgical sector is its economic relevance in the Brazilian economy. The revenue in 2011 was around US $\$ 85$ billion, with exports in the amount of US $\$ 21.5$ billion and imports of US $\$ 11.7$, according to data from the Brazilian Metallurgy Statistical Yearbook prepared by the Ministry of Mines and Energy (2012). Another feature that places the metallurgical sector in focus is that it works as a basis for other relevant activities, such as: the automobile industry, capital goods and construction. This last activity, cutting and folding of the steel that this sector elaborates, depends on the requests of customers or the demand of consumption of the products elaborated by the company case study, and it will be studied later.

\section{BIBLIOGRAPHIC REVIEW}

\subsection{Knowledge management}

Knowledge management is a set of organizational tactics aimed at creating, acquiring, making available, sharing and using knowledge appropriately for generating ideas, problem solving and decision making (Demarest, 1997). According to Nonaka et Takeuchi (1997) and Nonaka et Konno (1998), the two knowledge formats can undergo a conversion process. Conversion of knowledge is based on combinations of the two types of knowledge in four modes, which gives rise to the $\mathrm{SECl}$ model (socialization, externalization, 
combination and internalization), as presented in Table 1 (Costanzo et Sánchez, 2014).

According to authors, one or more conversions may occur simultaneously. And, it is not necessary to follow the order described by the SECI model, for some tactics such as metaphor, representation may cause the individual to have developed his own learning, and so he can "skip" stages of knowledge conversion. However, it is necessary to measure and monitor the KM process. The evaluation of its results is complex because it deals with intangible elements; however, it does not mean that it is immeasurable (Gonzalez et Martins, 2015; Arpaci, 2017).

For Mitchell (2003) knowledge management is a systematic process that includes the capture, creation and sharing of knowledge and learning. For the author, within his studies, he concluded that technology can be used as a facilitator of knowledge management.

For Sveiby (1998), the evaluation of the intangible assets in the KM is necessary for goals to be redirected and gains maximized. It can be organized into three groups of indicators: internal structure (investment in R\&D, career plan and systems of remuneration); (Relationship with clients and suppliers, dialogue with society) and skills (employee qualification, mutual trust, commitment and creativity).

\subsection{Quality management}

The last two decades have witnessed an increasingly greater preponderance and widespread adoption of quality management schemes (Zeng et al., 2017).

Quality management is seen today as a strategic factor for improving competitiveness and productivity. Its importance stems from a long evolution process of the concept and practice that had the contributions of several scholars.
Quality management aims to reduce waste and non-quality costs in production operations, improving business efficiency and enabling more competitive pricing. Thus, the less waste, the lower the costs; the greater the possibility of more competitive prices, the greater the chances of maintaining and conquering markets. This means positive results for the company and more competitiveness (Gambi et al., 2015; Barros et Slotboom 2017).

For Juran et Gryna (1991) quality management is a necessity for the survival of organizations. The authors affirm that the quality management in the organizations is given by the interrelationship of human components, which are composed by the collaborators of the organization and by the top management to improve the activities of the company; technological, which is the improvement of the process and of the productive system; and logical, through planning and control of processes and production systems. With these possible combinations of the components, the control in the quality management in the company can bring benefits such as the reduction of costs, the savings in terms of operating time and the expectation that keeps the operation within the programmed.

According to Paladini (1998), Quality Management is defined as being the set of strategies that, when organized, aim to produce quality in processes, products and services.

\subsection{Community of practice}

The expression "community of practice" is attributed to the researchers Lave et Wenger (1990). It is defined as informal, spontaneous organizations composed of practitioners within and outside the organizations in which they continue to exist, according to the identification of belonging and for similar purposes among the members of a group. For its formation, it is necessary to consider three elements: (i) practice - the contribution, the sharing and exchange of learning

Table 1. SECl knowledge conversion model

\begin{tabular}{cccc}
\hline Type & $\begin{array}{c}\text { Form of conver- } \\
\text { sion }\end{array}$ & Practical conversion form & How it is converted \\
\hline $\begin{array}{c}\text { Socializa- } \\
\text { tion }\end{array}$ & From tacit to tacit & $\begin{array}{c}\text { Dialogue, face-to-face communication; Brainstorm- } \\
\text { ing, observation, imitation and practice accompanied } \\
\text { by an instructor. }\end{array}$ & $\begin{array}{c}\text { Sharing experiences and mental models through } \\
\text { teamwork. }\end{array}$ \\
\hline $\begin{array}{c}\text { Out- } \\
\text { sourcing }\end{array}$ & $\begin{array}{c}\text { From tacit to } \\
\text { explicit }\end{array}$ & $\begin{array}{c}\text { Models, concepts, hypotheses, spreadsheets, texts, } \\
\text { images, figures, rules. }\end{array}$ & $\begin{array}{c}\text { Symbolic representation through metaphors / } \\
\text { analogies or deduction / induction, oral reports } \\
\text { and films. }\end{array}$ \\
\hline $\begin{array}{c}\text { Combi- } \\
\text { nation }\end{array}$ & $\begin{array}{c}\text { From explicit to } \\
\text { explicit }\end{array}$ & $\begin{array}{c}\text { Observation and analysis in models, concepts, hy- } \\
\text { potheses, spreadsheets, etc. }\end{array}$ & $\begin{array}{c}\text { Grouping, synthesis, classification and process- } \\
\text { ing of different explicit knowledge. }\end{array}$ \\
\hline $\begin{array}{c}\text { Internal- } \\
\text { ization }\end{array}$ & $\begin{array}{c}\text { From the explicit } \\
\text { to the tacit }\end{array}$ & $\begin{array}{c}\text { Reading / visualization and individual study of differ- } \\
\text { ent formats (texts, images, among others). }\end{array}$ & $\begin{array}{c}\text { Reinterpreting individual experiences and prac- } \\
\text { tices. It is learning itself (learning by doing). }\end{array}$ \\
\hline & & Source: Adapted from Nonaka and Takeuchi (1997).
\end{tabular}


between the members of a team; (ii) Community - the interaction between the members for knowledge management; (iii) domain - the subject to be dealt with in the interactions and for integration among the members. The community of practice has degrees of maturity, as shown in Figure 1.

The other key authors to describe this type of community are: Wenger (2006), Wenger et Snyder (2001). The latter were responsible for differentiating the forms of community of practice in a company, as described in Table 2.

One of the main formats of knowledge is the networks that connect people who are experienced and prepared to act in a group, interacting through the exchange of tacit knowledge (Allen 1977; McDermott, 1999). For Garvin (1993), a learning organization is one in which the individuals involved are skilled, have the ability to create (externalize), acquire (internalize) and disseminate (socialize) knowledge, and modify individual and collective behavior from reflection on knowledge. This reflection is, in itself, adaptive and cumulative learning, also called innovative by Argyris et Schon (1978).

A facilitator of conversions between tacit knowledge is the creative capacity of individual talents and the motivation for proposing unique ideas and solutions, sharing individual experiences provided by the organizational environment to employees, according to Senker (1995), Ghoshal et Na- hapiet (1998). Another facilitator for the explicit format of knowledge is the capacity to construct the lessons learned, meaning to record the experience, the errors raised and the solutions adopted, that is, it is the corporate memory that is composed of creative ideas and the analysis of failures and successes of everyday experiences.

These lessons are elaborated, dialogued and learned in communities of practice; in this sense the community must be fair (Argyris, 1980). It is based on principles of equity and democracy, causality and individual and collective responsibility for the well-being of all, promotion and creation of a climate of mutual trust, in which the understandings are externalized, heard and discussed in a mature way by all a particular company (Wenger, 2000). Organizations also need to create dynamic conditions capable of developing: intellectual capital, individual competencies, and the improvement of human resources with a greater degree of accountability for their actions and oriented to knowledge (Choo, 1996).

It is important to remember that non-shared knowledge becomes worn out and can be lost, hence the constant need for conversion through sharing in communities of practice. However, there are many barriers to knowledge sharing stemming from the organization's own physical layout, organizational culture, human resource management, and operational processes.

\section{STAGE OF DEVELOPMENT}

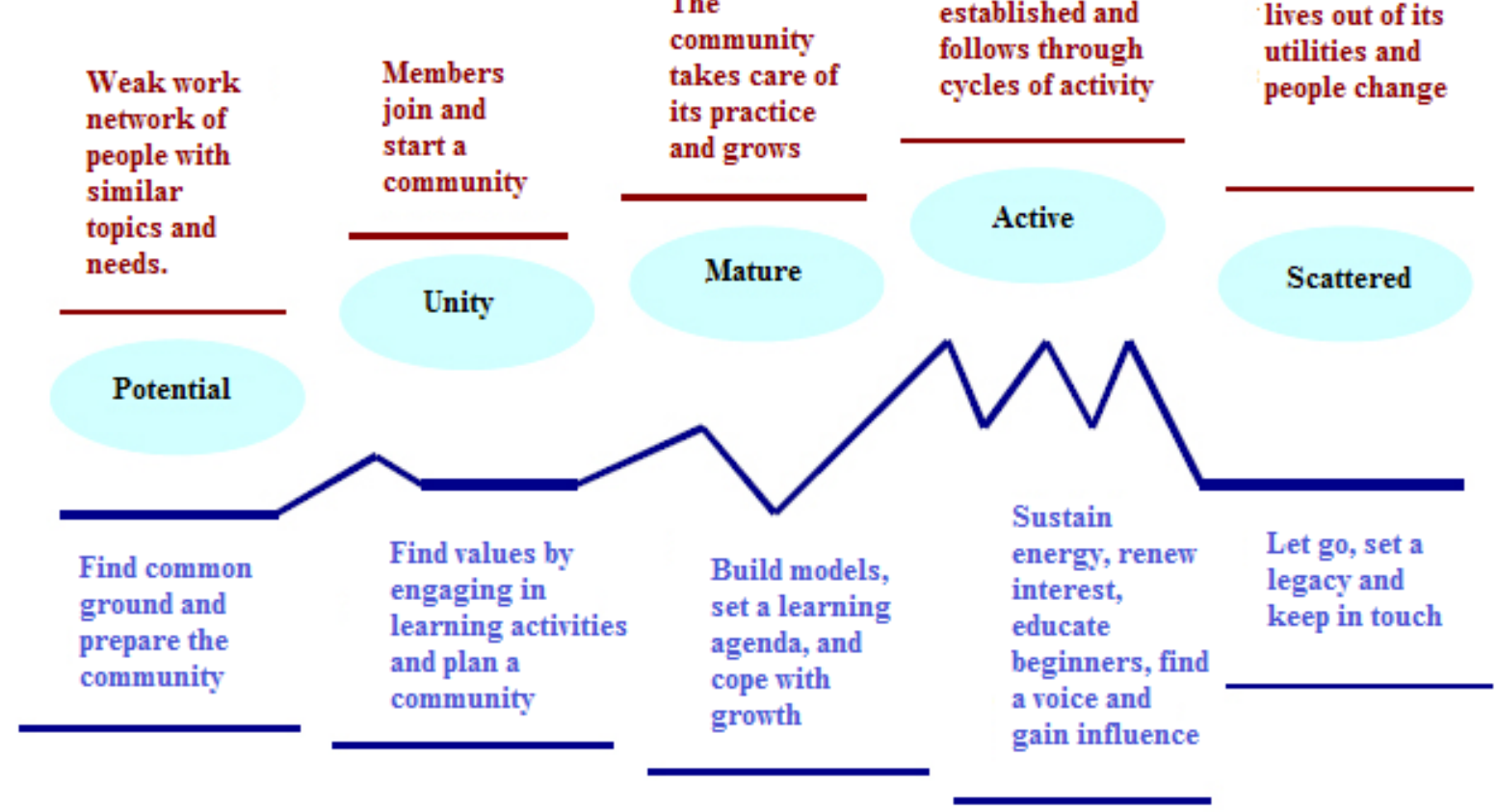

\section{TYPICAL ACTIVITIES}

Figure 1. Stages of the community for the development of practice. Source: Adapted from Wenger (1999). 
Table 2. Forms of community of practice

\begin{tabular}{|c|c|c|c|c|}
\hline Group & What's the point? & Who participates? & $\begin{array}{l}\text { What do they have } \\
\text { in common? }\end{array}$ & $\begin{array}{l}\text { How long do } \\
\text { they last? }\end{array}$ \\
\hline $\begin{array}{l}\text { Community of } \\
\text { practice }\end{array}$ & $\begin{array}{l}\text { Develop competencies of partic- } \\
\text { ipants; Generate and exchange } \\
\text { knowledge }\end{array}$ & $\begin{array}{l}\text { Participants who } \\
\text { self-select }\end{array}$ & $\begin{array}{l}\text { Passion, commitment and } \\
\text { identification with the group's } \\
\text { expertise }\end{array}$ & $\begin{array}{l}\text { While there is an } \\
\text { interest in keeping }\end{array}$ \\
\hline $\begin{array}{l}\text { Formal Working } \\
\text { Group }\end{array}$ & Develop a product or service & $\begin{array}{l}\text { Anyone who pres- } \\
\text { ents to the group } \\
\text { manager }\end{array}$ & $\begin{array}{l}\text { Job Requirements and Com- } \\
\text { mon Goals }\end{array}$ & $\begin{array}{l}\text { Until the next reor- } \\
\text { ganization }\end{array}$ \\
\hline Project Team & Performing a certain task & $\begin{array}{l}\text { Employees Chosen } \\
\text { by Senior Manager }\end{array}$ & $\begin{array}{l}\text { The goals and important } \\
\text { points of the Project }\end{array}$ & $\begin{array}{l}\text { Until the end of the } \\
\text { project }\end{array}$ \\
\hline $\begin{array}{l}\text { Informal Net- } \\
\text { work }\end{array}$ & $\begin{array}{c}\text { Scoop and transmit business } \\
\text { information }\end{array}$ & $\begin{array}{l}\text { Friends and } \\
\text { acquaintances of } \\
\text { business }\end{array}$ & Mutual needs & $\begin{array}{l}\text { As long as people } \\
\text { have a reason to } \\
\text { stay in touch }\end{array}$ \\
\hline
\end{tabular}

Source: Wenger and Snyder (2001).

Thus, for the development of internal skills of employees, it is necessary to create environments that stimulate creativity, favor moments for more dynamic exchanges of knowledge (tacit or explicit), as well as a broad set of tools, such as: Databases, studies, reports, and various information (Nonaka et Takeuchi, 1997). It is on the basis of this exchange of experiences that knowledge management can be aligned with the concept of community of practice.

\section{METHODOLOGY}

The purpose of a study is to approximate the analysis of a phenomenon and the truth of its facts, so it is important to characterize the scientific method used to perform this work. It is understood by method as a set of artifices to analyze the phenomenon (Gil, 2010).

After this clarification, it can be considered that the scientific method adopted in this work was the descriptive case study of transversal analysis, since its objective is to study the characteristics of how the application of the knowledge is made in the decision making for quality management.

For this study, the application of questionnaires, and onsite observation, containing specific items that analyze the elements in a given period (Hair et al., 1995), were used. The following are the constituents of the research method used by this present work.

\subsection{Phases of the research}

The first phase is composed of bibliographical research, data collection on the subject in material available in books and scientific articles already published (Gil, 2010) and that will be the main support for this research.
The last stage of the work comprises the confrontation between the data obtained in the primary and secondary sources.

\subsection{The sample}

The sample and place of application of the questionnaires were intentionally selected, through the accessibility of the researchers of this study. The company studied is large, has the main activity in the service centers, cutting and folding steel for civil construction. It is located in an industrial area of Pernambuco and has 250 employees. In the present study, data collection was performed with 180 interviews, approximately $72 \%$ of the employee population at all hierarchical levels of the organization case study.

The service centers treat steel in a customized and individualized way, as it works with unique structural projects, meeting the needs of each construction site. Each structural design has several pieces that will be used, for example, in the frames of a beam and on the slabs and pillars of a building. The parts are manufactured by advanced technology equipment capable of guaranteeing accuracy in all sizes and formats of steel cutting and bending. The parts are delivered according to the need and request of the client's term and are labeled indicating the name of the element, the design, the format and the size of the part and other requisitions requested by the client, in which it contributes to the organization of the construction site.

Before making cuts, the company prepares a study to minimize possible leftovers. For this, it is opportune to respect the characteristics of steel based on the Brazilian Regulatory Standards, NBR 7480 (laboratory standard that establishes the requisites for ordering, manufacturing and supplying steel bars and wire) and NBR 6118 (standard dealing with requirements of basic design of a simple, reinforced and pre- 
Brazilian Journal of Operations \& Production Management

Volume 15, Número 1, 2018, pp. 1-11

DOI: 10.14488/BJOPM.2018.v15.n1.a1 stressed concrete structure, that is, they are standards in the work, which will use the steel made by the company case study), which deals with the folding diameter. This, in turn, can vary according to the diameter and grade of the steel.

\subsection{Procedures for collecting and analyzing data}

The questionnaire was used as the primary technique for the collection of primary data (Vergara, 2015), and its preparation was based on the elements present in the bibliographic reference.

\subsection{Presentation of research data}

The main factors about the alignment between knowledge management and communities of practice are described below.

\subsubsection{Total Quality Management Policy}

At this point all respondents demonstrated that they know deeply about the policy of the company's total quality management case study, that is, the dissemination and awareness of quality concepts are occurring in an appropriate manner. The internal communication is the main element for understanding and knowledge by all 180 employees about quality policy.

An important fact is that the requirements of NBR ISO 9001:2015 permeate the conversion of knowledge, in which top management must make sure that it has the necessary tools and tactics so that the quality policy is communicated and understood by everyone in the organization.

Another important point for the communication process is the location of quality indicators. In order to establish this internal communication, $95 \%$ of the interviewees know where the quality indicators in the management teams are located.

In this same sense, the following objectives were evaluated: the goals, the quality indicators, and the operational procedures are known by about $80 \%$ of the employees, according to the research carried out. At this point, the NBR ISO 9001:2015 standard addresses the necessary combination and internalization of instructions to ensure the effective operation and control of quality management processes. From NBR 7480 and NBR 6118, applied to the folding of steel in laboratories and works respectively, it is possible to disseminate and follow operational procedures in which the company provides reduction of leftovers, as for example: the use of bending pins with correct diameters in parts such as stirrups or irons in L-shaped format allows reducing tips and increasing profits.

\subsubsection{Internal improvement: use of knowledge}

At this point we analyzed the continuous improvement programs that are known to $75 \%$ of the employees. Many of the employees participate individually reflecting on the subject to be improved and collectively providing information on the causes and effects for the drafting of a corrective action plan. In this way, the phenomenon of externalization of ideas and suggestions occurs.

With regard to company improvement plans of the case study, it is opportune to comment on the audit processes that it is submitted. In the audit process, $87 \%$ of employees have already been audited at least once. When outsourcing occurs in the company, it promotes the standardization of internal organization procedures.

\section{DISCUSSION OF COMPANY RESULTS CASE STUDY}

The community of practice in the company case study can be seen as a social learning system, whose main objective is to develop competence of each employee at the moment that the exchange of information, suggestions and knowledge occur. This change comes from individual learning in the most critical moments or situations experienced, as for example: lack of equipment to develop a project with shorter operational time. The creation of communities of practice does not occur at random, and it has a specific time of beginning and end. In this research, this is the scheduled time for each steel cutting and bending project. According to Wenger et al., (2002) the main features of a social learning system found in the company case study are:

- Domain: it is the identity defined by a shared domain of interest, of commitment to share the competence of each employee. They value the collective competence of learning from each other. Managers who do not participate in this informal group, value and recognize that shared knowledge is a form of training and technical improvement of the members who belong to the group.

- Community: Members engage in joint activities and discussions, tend to help each other, and share information. They build relationships that allow them to learn from each other. The only problem for the community is when the parts are delivered under pressure, since most of the time people are assigned with extra activities, which leads to more limited communication.

- Practice: members develop their experiences, histories, tools, ways of solving recurring problems in a shared way, with the purpose of stimulating the cre- 


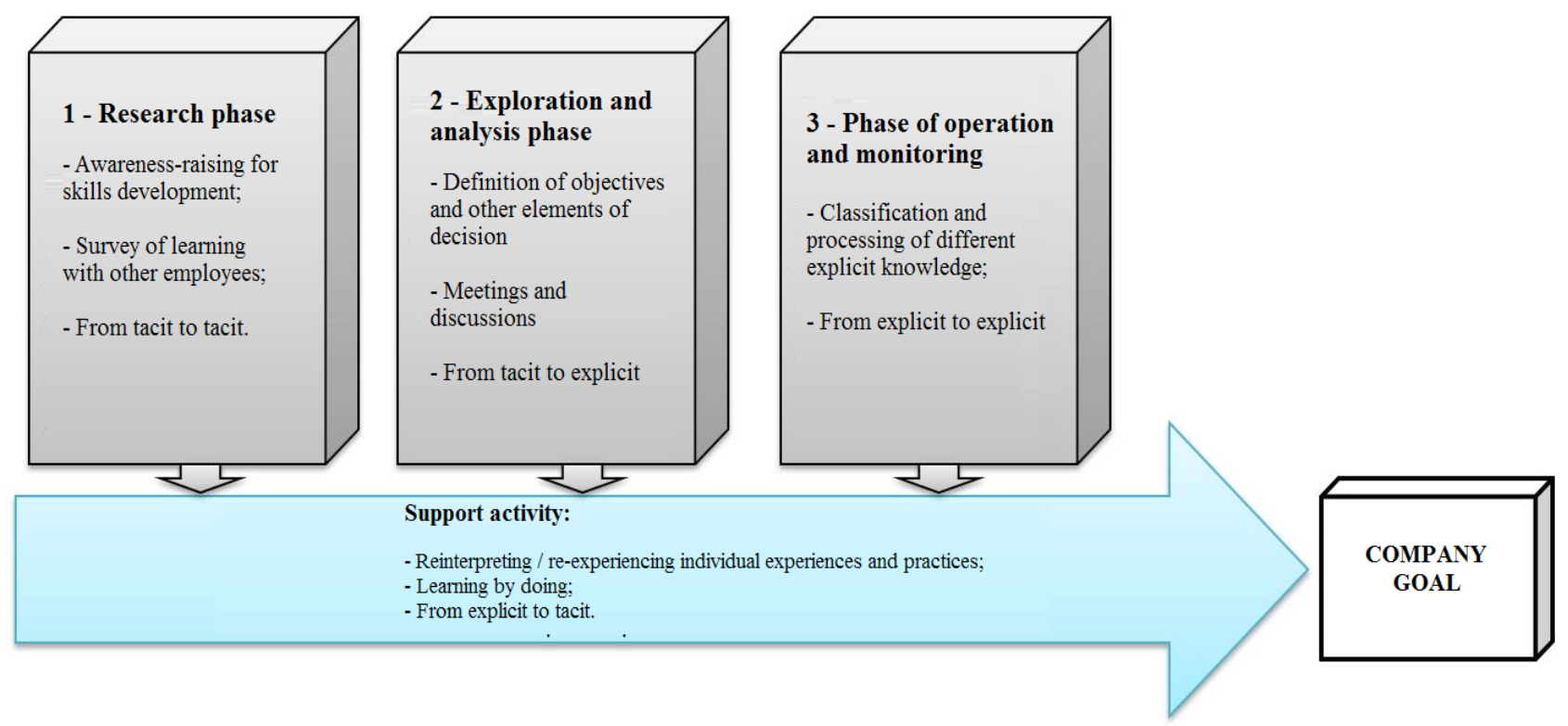

Figure 2. Characteristics of the company's social learning system case study. Source: The Authors (2017).

ative process for the appropriate use of the resources available by the company in performing steel cutting and bending.

- Engagement: closer relationship for doing things; the individual can work alone or together with other people, talking, and using and producing steel parts. It can be understood for the provision of work if it is the experience of competence or incompetence and whether the development of a job provides an identity of participation or non-participation among employees.

- Imagination: it is the way each individual relates, building his image of belonging to a particular social group. It is the image of all employees and how each of them is seen within the organizational collective. Each employee begins to reflect on his situation and to explore new possibilities through the tools of imagination (for example: metaphors, analogies, images, quality programs, models, ISO rules, among others). These images compose the interpretation of the participation of each individual in the collective of the company, and the self-learning.

Figure 2 groups together all the characteristics featured and presents them for the formation of the learning system of the company case study. It is necessary to have a base or operational support for learning what to do, just as all activities and employees must have a strategic goal established by the company.

The study also identified four other factors for establishing the practice community, focused on the resolution of issues related to the internal quality management of the company case study, as shown in Figure 3.

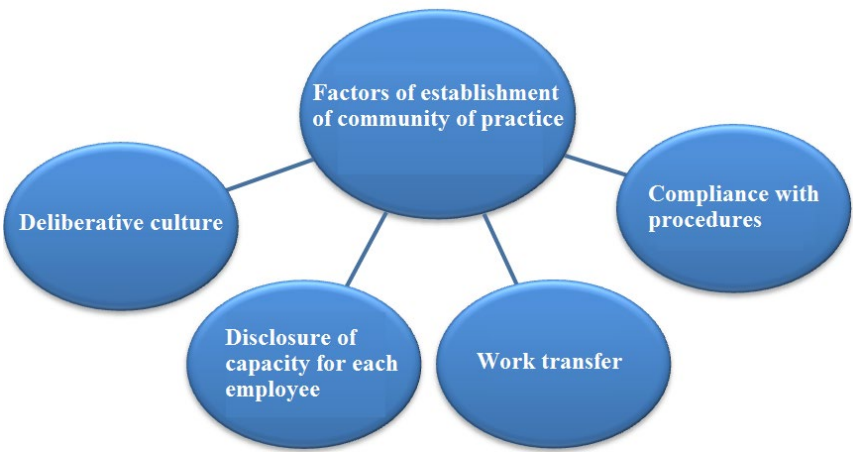

Figure 3.Factors for the establishment of the community of practice. Source: The Authors (2017)

1. Compliance with the procedures: commitment to meet, dialogue on how best the production objectives, technical instructions and procedures should be followed.

2. Work transfer: each older employee goes through examples developed in practice, elaboration of metaphors and analogies so that the learning of the new employees takes place. And, in this way, it can provide employees with proactive attitudes, knowledge, skills, and belonging to the group, since all employees have the feeling of working as a team.

3. Disclosure of the load / capacity for each employee: every employee can make the combination between 
tacit and explicit knowledge, adjusting the resources of the company and how to use them, since they are busy all the time and have no idleness margin. In this way, employees can improve their effectiveness in response to an adjustment of information on how to best use their time in each equipment device. However, the research also showed that communication is deficient among technicians, supervisors and managers. When the claimant demands a shorter time frame, the delivery of the parts is under pressure, and it is very common not to communicate the failures and successes of the productive process, when this operational situation occurs.

4. Deliberative culture: allows employees to give their opinion and propose improvements that are accessible financially and operationally in their work environment.

As for for knowledge management, two lessons were found and both make employees more experienced (obtaining learning through practice or living and systematically improving the way of working overtime), as well as they make the company more cohesive and integrated with its set of guidelines and recommendations for quality management. These are the lessons identified:

Everyone's involvement to solve the problem, because, in many projects, there are no adequate resources available: lack of equipment, instructions or physical limitations can contribute to the wrong development of steel bending or cutting. In this way, employees tend to discuss how they can design project parts, even if they do not have the tools to do it. They are attempts to externalize tacit knowledge and group or combine explicit knowledge to develop new ways of using old equipment in projects with more technical specificity.

Employees learn from the planning error when there is time pressure. When the request is processed with an urgent status, informal network-based collaboration training, in which the four forms of the $\mathrm{SECl}$ model are accessed, emerges. First, there is socialization, which creates shared knowledge; then there is the externalization that is the exchange of tacit for explicit knowledge. There is the formation of conceptual or technical knowledge base for the operationalization of the requirements of the parts of the steel cutting and bending project. It is worth mentioning that these design requirements, are elaborated by the client. The company studied works the parts that are in the project in the best way, according to the limitations and restrictions imposed by the production system itself; then the combination occurs when the new ways of working are grouped and processed in a register, generating the systemic knowledge for the company to solve the same problem, or the same situation in future periods; finally, internalization occurs, in which the operational knowledge is generated; it is linked to the action and it is fundamental for the development of organizational and individual competences.

Another very important observation is about the development stage of the community of practice to which the company case study is linked. For this, the community of practice is established and follows through its project development cycles, because as each one has limitations, obstacles and unique operational implementation, the community is formed through cycles of activities that involves each employee and has the responsibility to meet the requirements of demand. That is, it is an Active Practice Community, which has support in terms of energy and common interest and which is shared by the team. The main benefits of this degree of maturity for the company are: quick problem solving with more creative and more efficient ideas, and faster dissemination of managerial practices, such as total quality management.

For the community, the advantages are: building a unique language and communication around the group's competences, retaining knowledge by disseminating and sharing knowledge and expertise to a larger number of employees. And for individuals, the benefits are: helping in the accomplishment of their work, helping on the development of their skills and competences through learning by doing, stimulating the sense of identification and belonging to colleagues and the organization.

\section{COMMUNITY OF PRACTICE AND KNOWLEDGE MANAGEMENT FOR THE COMPANY CASE STUDY}

In this section we will analyze the alignment between the knowledge management and the practice community of the steel cutting and bending company. In order to reach this alignment, it is important to consider that knowledge is acquired through the process of information sharing. Such consideration leads us to affirm that information is the raw material for the company employees' case study.

Figure 4 shows several training cycles. The most external cycle refers to the organizational management of the company with a focus on continuous process improvement, and in this case, steel cutting and bending. For this to occur, it is necessary to develop the organizational culture focused on continuous learning and aim at creating value for organization and as a strategy for innovation and problem solving.

Also, in the aforementioned figure, the alignment between the flow of knowledge generation and its use by the practice communities of the company is also presented. For, with the greater use of this raw material, the emphasis will 
also grow on successive passages between tacit and explicit knowledge (Allen, 1977; Gupta et Govindarajan 2000). This analysis is in the internal cycle that has the gray coloration that has the characteristic to develop the spiral of the SECI model, for phase investigation, exploration and analysis, and operation and monitoring. In the first phase of research the company must organize and encode the information. This phase is mainly focused on the generation and internal accumulation of information in the organization; however, it can be used in decision-making processes. For this, there must be the standardization of language, classification, manipulation and codification of information, which solves the problem of retrieval.

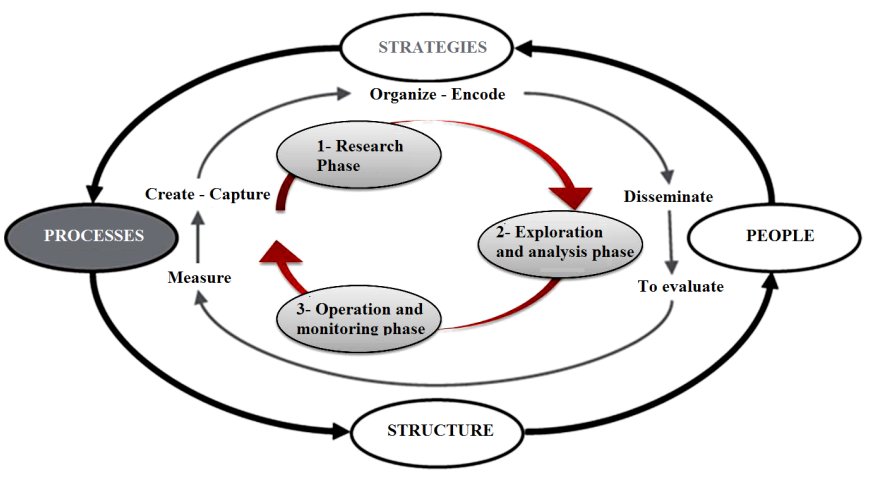

Figure 4. Alignment of knowledge management and practice community in the enterprise case study. Source: The Authors (2017)

On the second phase of exploration and analysis, the dissemination and evaluation of information is elaborated. New practices and tools are introduced to bridge the gap between what is being done in the organization and the best practices validated outside the company. And in the third phase of operation and monitoring, the actions of measurement, creation and capture take place. For this, the organization considers all types of documents, defining where they will be stored, how to register and follow up on their process. Concern in terms of saving information is related to having it available when it is necessary for decision making, through registration and conservation and protection of information in a database suitable for the reduction of possible losses and wastes (human resources, Material and financial) in improperly made decisions. In this view, information is seen in an expanded way as the capacity for business action (Wenger, 2000).

Another highlight of the company case study is the cash management frameworks. They can be understood as conscious overlapping of information, activities and managerial responsibilities, especially when functional areas for the steel cutting and bending process are involved, since for the development of the product requires a single view of work vision. It is crucial to have processes that can improve the ability of teams to develop special skills (Argyris, 1980).
In this sense, communities of practice can be observed as a fundamental resource for organizations, to develop and manage knowledge and skills, and also to help managers work with this resource in the search for competitive advantage for the company case study (Ghoshal et Nahapiet, 1998).

Therefore, new skills are developed and associated with operational tactics, allowing the company case study to explore new fields, experience new challenges, and implement new ideas. By virtue of the greater generation of communities of practice, the opportunities for value creation can be more easily perceived.

Through the observation of the case study company's data, we can see that it is in the maturity phase regarding the development of knowledge management as a community of practice. This phase is characterized by the support and recognition of the learning organization, in which its members know how to generate and store the content of all the information generated. The company can also help this development by improving its organizational policies, starting to have a sustainable human resources management, promoting the stability of the membership.

Thus, the focus of learning in this case study is not simply the development of analytical capacity. For, based on the information generated in these phases through teams working together in communities of practice, one may or may not acquire the knowledge expected for learning and for decision making.

\section{CONCLUSION}

The Knowledge management requires a new way of managing human resources. People cannot be seen as an operational element that is only able to operationalize the company's goals and projects. They can learn, discuss and comment on how best to develop their work in an individual way and thereby encourage other members of the company to improve their work technique and use the internal resources of the company in a more rational and optimized manner. It is not enough just to invest in qualification; it is necessary to invest in the promotion of changes and attitudes of the employees, so that there is a greater degree of responsibility, autonomy in terms of the decision making of the operational actions as for freedom of action and creativity.

In this sense, it can be said that the main difference between companies in the competitive environment is how they can learn, developing their activities and thus improving continuously through KM. 
Table 3. Alignment between knowledge management and community of practice

\begin{tabular}{|c|c|c|c|}
\hline \multirow{2}{*}{ Rating Criteria } & \multicolumn{3}{|c|}{ Management Activities } \\
\hline & Strategic Alignment & Routine Planning & Problem Resolution \\
\hline Objective & $\begin{array}{l}\text { Comply with Standards NBR ISO } \\
\text { 9001:2015, NBR } 7480 \text { and NBR 6118; } \\
\text { Definition of the company focus. }\end{array}$ & $\begin{array}{l}\text { Articulation of employees; } \\
\text { Detail key processes; } \\
\text { Maintain and create communica- } \\
\text { tion mechanisms. }\end{array}$ & $\begin{array}{l}\text { Information management and mon- } \\
\text { itoring; } \\
\text { Process quality assurance; } \\
\text { Joint elaboration of problem solving. }\end{array}$ \\
\hline Product & Identification of needs. & $\begin{array}{l}\text { Map actor and profile; } \\
\text { Manage ad hoc }\end{array}$ & $\begin{array}{l}\text { Establishment of the process for } \\
\text { handling problems; } \\
\text { Use of "use of product" reports. }\end{array}$ \\
\hline $\begin{array}{l}\text { Methods and } \\
\text { tools }\end{array}$ & $\begin{array}{l}\text { Communication Mechanism (Mar- } \\
\text { ket> Company); } \\
\text { Engagement of the actors; } \\
\text { Articulation of processes. }\end{array}$ & $\begin{array}{l}\text { Detailing and sequencing of activ- } \\
\text { ities; } \\
\text { Communication Mechanism (Com- } \\
\text { pany> Customer). }\end{array}$ & $\begin{array}{c}\text { Document management } \\
\text { Search and database tools; } \\
\text { Mapping processes for improvement. }\end{array}$ \\
\hline
\end{tabular}

Source: The Authors (2017)

For the company case study, some considerations are: (i) to elaborate an individual development plan for the employees according to the main production functions of the company (the GC should opt for the use of formal manuals - required by the ISO and informal manuals - of good practices in procedures of errors, failures and possible non-routine elements that may influence or lead to a decision-making process). In these informal manuals of critical analysis, the lessons learned and the solutions that the company can take in similar situations will be included, enabling the quality management for the company's sustainability case study; (ii) to develop and implement meeting circles for the management of quality failures, within which the processes characterized as bottleneck, failures to elaborate steel cut and fold, requirements that consumers most appreciate with the cut and steel bending, the priorities regarding the use of machines and the raw material in times of peak / urgency, among other problems, should be studied, Thus stimulating and developing, indirectly, the very formation of the employees' competences.

\section{REFERENCES}

Allen, T. J. (1977), Managing the flow of technology: technology transfer and the dissemination of technological information within the R\&D organization, The MIT Press, Cambridge.

Argyris, C. (1980), Inner contradictions of rigorous research, Academic Press, New York.

Argyris, C.; Schon, D. (1978), Organizational learning: a theory-in-action perspective, Addison Wesley, Reading.

Arpaci, I. (2017), "Antecedents and consequences of cloud computer adoption in education to achieve knowledge management", Computer in Human Behavior, Vol. 70, 382-90.

Barros, N. P.; Slotboom, J. (2017), "Quality management in in vivo proton MRS", Analytical Biochemistry, Vol. 529, 98-116.

Choo, C. W. (1996), "The knowing organization: How organizations use information to construct meaning, create knowledge and make decisions", International Journal of Information Management, Vol. 16, No. 5, 329-40.

Costanzo, B. P.; Sanchez, L. E. (2014), "Gestão do conhecimento em empresas de consultoria ambiental", Production Journal, Vol. 24, No. 4, 742-59.

Demarest, M. (1997), “Understanding knowledge management", Long Range Planning, Vol. 30, No. 3, 321-22.

Fresneda, P. S. V.; Goulart, S. M. (2006), “A experiência brasileira na formulação de uma proposta de política de gestão do conhecimento para a administração pública federal", Câmara dos Deputados, Brasília, available at: http://www.bibl. ita.br/PoliticaGC.pdf, (access 2017 Jul 10).

Gambi, L. N. et al. (2015), "The relationship between organizational culture and quality techniques, and its impact on operational performance", International Journal of Operations \& Production Management, Vol. 35, No. 10, 1460-84.

Garvin, D. (1993), "Building a Learning Organization", Harvard Business Review, pp. 78-91, available at: https://www. ncbi.nlm.nih.gov/pubmed/10127041. (access 2017 Jul 10).

Ghoshal, S.; Nahapiet, J. (1998), "Social capital, intellectual capital, and the organizational advantage", Academy of Management Review, Vol. 23, No. 2, pp. 242-66, available at: http:// links.jstor.org/sici?sici=0363-7425\%28199804\%2923\%3A2\%3 C242\%3ASCICAT \%3E2.0.CO\%3B2-O. (access 2017 Jul 10).

Gil, A. C. (2010), Como elaborar projetos de pesquisa, 5 ed., Atlas, São Paulo.

Gonçalves, L. C. et al. (2009), "Um estudo sobre a adoção de práticas de gestão do conhecimento em organizações cooperativas", Production Journal, Vol. 19, No. 1, 163-69.

Gonzalez, R. V. D.; Martins, M. F. (2015), "Gestão do conhecimento: uma análise baseada em fatores contextuais da organização", Production Journal, Vol. 25, No. 4, 834-50.

Gupta, A. K.; Govindarajan, V. (2000), "Knowledge management's social dimension: lessons from Nucor Steel", Sloan Management Review, Vol. 42, No. 1, 77-80, available 
at: http://sloanreview.mit.edu/article/knowledge-managements-social-dimension-lessons-from-nucor-steel/. (access 2017 Jul 10).

Hair, J. S. et al. (1995), Multivariate Data Analysis, Prentice-Hall, New Jersey.

Juran, J. M.; Gryna, F. (1991), “Controle da qualidade handbook", in: Conceitos, políticas e filosofia da qualidade, Mc Graw-Hill, São Paulo.

Lave, J.; Wenger, E. (1990), Situated Learning: Legitimate Peripheral Participation, University of Cambridge Press, Cambridge.

Lopes, E. C.; Valentim, M. L. (2013), “Processos de Gestão da Informação: tratamento, recuperação e uso da informação no mercado de capitais", Perspectivas em Gestão \& Conhecimento, Vol. 3, No. 1, 157-74.

McDermott, R. (1999). "Learning across teams: How to build communities of practice in team organizations". Knowledge Management Review, Vol. 8, pp. 32-36.

Ministry of Mines and Energy (2012), "Brazilian Metallurgy Statistical Yearbook" available at: http://www.mme.gov.br/ documents/10584/1865251/Anuario_Setor_Metalurgico_ 2013_base_2012_parte_1.pdf/ac9ca050-9ab7-4e63-8c04-ca13903bfc9e (access 2017 Jul 10).

Mitchell, H. J. (2003), "Technology and knowledge management: Is technology just an enabler or does it also add value?", in Knowledge management: current issues and challenges, IRM Press, Hersey, pp. 66-78.

Nadler, D. A.; Tushman, M. I. (2000), “A organização do futuro", HSM Management, No.18, 58-66.

Nonaka, I.; Konno, N. (1998), "The concept of 'ba': building a foundation for knowledge creation", California Management Review, Vol. 40, No. 3, 40-54.

Nonaka, I.; Takeuchi, H. (1997), Criação de conhecimento na empresa, Campus, Rio de Janeiro.

Paladini, E. P. (1998), "As bases históricas da gestão da qualidade: A abordagem clássica da administração e seu impacto na moderna gestão da qualidade", Gestão e Produção, Vol. 5, $168-86$

Santos, I. C.; Amato Neto, J. (2008), "Gestão do conhecimento em indústria de alta tecnologia", Production Journal, Vol.18, No. 3, 569-82.

Senker, J. (1995), "Tacit knowledge and models of innovation", Industrial and Corporate Change, Vol. 4, No. 2, 425-47.

Sveiby, K. E. (1998), A Nova Riqueza das Organizações, Campus, Rio de Janeiro.

Vergara, S. C. (2015), "Métodos de pesquisa em administração". 6 ed. São Paulo: Atlas.

Wenger, E. (1999), Communities of Practice: learning, meaning, and identity: learning in doing: social, cognitive and computational perspectives learning in doing, Cambridge University Press, Cambridge.

Wenger, E. (2000), "Communities of practice and social learning systems", SAGE Social Science Collections, Vol.7, No. 2, 225-46.

Wenger, E (2006), "Communities of Practice: a brief introduction", available at: https://www.ohr.wisc.edu/cop/articles/ communities_practice_intro_wenger.pdf (access 2017 Jul 10).

Wenger, E.; Snyder, W. (2001), "Communities of Practice", in Harvard Business Review (Org.), Aprendizagem Organizacional, Campus, Rio de Janeiro.

Wenger, E. C.; Mcdermott, R.; Snyder, W. C. (2002), “Cultivating Communities of Practice: A Guide to Managing Knowledge". Harvard Business. Boston, MA.

Zeide, E.; Liebowitz, J. (2012), "Knowledge management in law: A look at cultural resistance", Legal Information Management, Vol. 12, No. 1, pp. 34-38.

Zeng, J. et al. (2017), "The Impact of Organizational Context on Hard and Soft Quality Management and Innovation Performance", International Journal of Production Economics, Vol.185, 240-51.

Received: Jul 20, 2017

Approved: Jan 12, 2018

DOI: 10.14488/BJOPM.2018.v15.n1.a1

How to cite: Jerônimo, T. B., Melo, F. J. C., Aquino, J. T. et al. (2018), "Knowledge management alignment to the community of practice in a company of cutting and bending steel", Brazilian Journal of Operations \& Production Management, Vol. 15, No. 1, pp. 1-11, available from: https://bjopm.emnuvens.com.br/bjopm/article/view/370 (access year month day). 